Agro-Science Journal of Tropical Agriculture, Food, Environment and Extension Volume 17 Number 1 (January 2018) pp. 35 - 43

ISSN 1119-7455

\title{
GROWTH AND YIELD VARIABILITY OF GROUNDNUT (Arachis hypogaea L.) CULTIVARS INFECTED WITH COWPEA APHID-BORNE MOSAIC VIRUS DISEASE
}

\author{
${ }^{* 1}$ Ayeleke D.A., ${ }^{2}$ Salaudeen M.T. and ${ }^{2}$ Gana A.S. \\ ${ }^{1}$ Federal Department of Agriculture, \\ Federal Ministry of Agriculture \& Rural Development, PMB 135, Garki, Abuja \\ ${ }^{2}$ Department of Crop Production, \\ Federal University of Technology, PMB 65, Minna, Niger State, Nigeria \\ *Corresponding author’s email: ayelekedaud@yahoo.com
}

\begin{abstract}
Groundnut (Arachis hypogaea) is a major legume crop with diverse uses in Nigeria. Its productivity is however threatened by Cowpea aphid-borne mosaic virus (CABMV) in most groundnut producing areas, resulting in huge losses. This study was conducted to determine the resistance of some commercial groundnut cultivars under CABMV disease. The experiment was conducted in Minna, Southern Guinea Savanna agro-ecological zone of Nigeria. Twenty groundnut cultivars were evaluated separately as healthy and CABMV infected trials. The experiment was laid out in randomised complete block design with three replications. Seedlings were infected with the virus by mechanical inoculation at 10 days after sowing. The plants were observed for disease incidence, growth and yield attributes. The data collected were subjected to analysis of variance, principal component and cluster analyses at $p \leq 0.05$. One hundred percent infection was found regardless of the cultivar. The healthy plants exhibited significantly $(p<0.05)$ higher morphological and yield parameters than infected plants. Principal component analysis revealed that 100-seed weight accounted for the greatest variability in healthy (eigen vector $=0.6239)$ and CABMV infected (eigen vector $=$ $0.6005)$ plants. Cluster analysis showed that $18(90 \%)$ cultivars formed cluster 1, whereas one cultivar each was found in cluster 2 and 3. The top three cultivars for 100-seed weight: "SAMNUT 23" $(56.0 \mathrm{~g})$, "SAMNUT 25" (50.5 g) and "SAMNUT 26" (50.9 g) were the most tolerant to CABMV, whereas "ICG92267" was identified as the best cultivar for dry matter production $(24.0 \mathrm{~g} /$ plant). Planting of these tolerant cultivars is recommended in order to mitigate the stresses imposed by CABMV.
\end{abstract}

Key words: disease incidence, principal components, clusters, groundnut

\section{INTRODUCTION}

Groundnut (Arachis hypogaea L.) is an important grain legume in tropical cropping systems of Africa which is typically grown in subsistence nature by resource poor farmers (Haussmann et al., 2012). Cultivated groundnut originated from South America (Scott and Vikas, 2014). It is an annual oilseed and food legume crop grown in numerous environments all over the world between $40{ }^{\circ} \mathrm{N}$ and $40{ }^{\circ} \mathrm{S}$. Groundnut is ranked fifth position among oilseed crops worldwide after oil palm, soyabean, rapeseed and sunflower (FAO, 2014). It serves as an excellent source of plant-based protein and contains high contents of various minerals, vitamins and plant compounds (Muhammad et al., 2013). Its haulms are essential animal feed containing 8-15\% protein, 1-3\% lipids, 9-17\% minerals, and 38-45\% carbohydrates (Janila et al., 2016). Groundnut is used as therapeutic food in Africa and many developing nations of the world to combat malnutrition in children (UNICEF, 2007). It has been found to produce more oil per hectare than any other food crop hence possibilities are being considered to explore it for bio-diesel production (Prasad et al., 2011). Groundnut is commonly grown in intercrops due to its nitrogen fixing ability thereby enriching the soil for other crops (Konlan et al., 2013). Studies have shown that groundnut could fix between 40 and $80 \mathrm{~kg} \mathrm{~N}$ per hectare in one year (Janila et al., 2013).

In sub Saharan Africa, 32 viruses induce yield losses in groundnut and the major ones are Cowpea aphid-borne mosaic virus (CABMV), Cucumber mosaic virus (CMV), Indian peanut clump virus (IPCV), Peanut clump virus (PCV), Peanut mottle virus (PeMoV), Peanut streak virus (PStV) and Cowpea mild mottle virus (CPMMV-severe strain) (Sastry and Zitter, 2014). All these viruses are transmitted through groundnut seed and are regarded as important quarantine pests. Cowpea aphid-borne mosaic virus has been known in Nigeria since 1976 as a devastating virus disease of legume in all the agro-ecological zones (Shoyinka et al., 1997). The virus has flexuous filamentous particles raging from 727 to $765 \mathrm{~nm}$ in length and 
$11 \mathrm{~nm}$ wide (Damiri et al., 2013). It is a potyvirus whose particles are not affected by $\mathrm{Mg}$ ions (Luis et al., 2013). Most often, the fecundity of CABMV soars under field conditions through increased aphid populations, availability of susceptible host plants and the presence of initial infection foci (Luis et al., 2013). Infection due to CABMV has resulted in yield losses that ranged from 13 to $87 \%$ and sometimes total crop loss could be encountered depending on the level of susceptibility of the cultivars (Alegbejo, 2015). Besides sole infection, CABMV can co-exist with other viruses like Cowpea mottle virus (CPMoV) or CMV (Arogundade et al., 2010), causing a mixed or combined infections with more damaging effect on farmers' field. Although a lot of studies have been conducted to determine the pathogenicity of CABMV disease on cowpea there is scanty information on the effect of the virus on groundnut in Nigeria. Groundnut cultivars with in-built characteristics of CABMV disease resistance have the potential to produce higher yields on farmers' fields. Knowledge of the resistance status of commercial groundnut cultivars would contribute to Nigeria's food security. Therefore, the objective of this study was to evaluate 20 commercial cultivars of groundnut for CABMV resistance in Southern Guinea Savanna agro-ecological zone.

\section{MATERIALS AND METHODS}

\section{Study Location}

The study was conducted at the Teaching and Research Farm, Federal University of Technology, Minna during the 2016 cropping season. The coordinates of the site were $9^{\mathrm{O}} 51^{\prime} \mathrm{N}, 6^{\mathrm{O}} 44^{\prime} \mathrm{E}$ and $212 \mathrm{~m}$ above sea level. The site of the experiment is located in the Southern Guinea Savannah ecological zone of Nigeria. The mean annual rainfall is $1200 \mathrm{~mm}$ and is distributed between April and early October of each year. Temperature ranges between $35.0{ }^{\circ} \mathrm{C}$ and $37.5{ }^{\circ} \mathrm{C}$ while relative humidity varies from 40 to $80 \%$. According to Adeboye et al. (2011), soils in Minna are generally classified as Alfisols.

\section{Source of Groundnut Seeds}

The groundnut cultivars ("FDRF7-61", "FDRF767”, “ICG-01276”, “ICG-02189”, “ICG-5159”, "ICG-6654", "ICG-92267", "ICG-94169”, “ICGIS-13003”, “ICG-IS-13986", “ICGV-91317”, "ICGV-IS-76855", "SAMNUT 10", "SAMNUT 14", “SAMNUT 21”, “ SAMNUT 22”, "SAMNUT 23", "SAMNUT 24", "SAMNUT 25", and "SAMNUT 26") used for the experiment were collected from the Institute for Agricultural Research (IAR), Samaru, Zaria, Kaduna State, Nigeria. These are commercial varieties of groundnut which are already being grown by farmers across the country especially in Minna, Southern Guinea Savanna agro-ecological zone where the study was conducted. They are early to medium maturing, dual purpose (kernel and haulm) with $45-50 \%$ oil content.

\section{Treatments, Experimental Design and Field Layout}

The twenty groundnut cultivars served as the treatments. Each cultivar was evaluated separately as infected and control (healthy). The experiment was laid out in randomised complete block design with three replications. The overall plot size was 40 $\mathrm{m} \times 12 \mathrm{~m}\left(480 \mathrm{~m}^{2}\right)$. The plots containing the infected plants had a total size of $15 \mathrm{~m} \times 2 \mathrm{~m}$ (30 $\mathrm{m}^{2}$ ) containing 20 rows of $2 \mathrm{~m}$ long each with an alley of $3 \mathrm{~m}$ between the replicates. Uninfected (control) plots of each cultivar also had a total size of $15 \mathrm{~m} \times 2 \mathrm{~m}\left(30 \mathrm{~m}^{2}\right)$ containing 20 rows of $2 \mathrm{~m}$ long each with an alley of $3 \mathrm{~m}$ between the replicates. The infected and control plots were established side by side with an isolation distance of $10 \mathrm{~m}$ in order to prevent virus contaminations.

\section{Source and Multiplication of Virus Inoculum}

The CABMV isolate used was obtained from the stock in the Department of Crop Production, Federal University of Technology, Minna. The inoculum was multiplied in the screen house to obtain enough quantity required for the field work. This was accomplished by planting susceptible cowpea cultivar (Ife Brown) into 20 pots at 5 plants per pot. The plants were infected with CABMV extract at 10 days after sowing. Inoculation of the cowpea seedlings was carried out after grinding the inoculum ( $1 \mathrm{~g}$ of CABMV infected leaf) in inoculation buffer $(0.1 \mathrm{M}$ sodium phosphate dibasic, $0.1 \mathrm{M}$ potassium phosphate monobasic, $0.01 \mathrm{M}$ ethylene diamine tetra acetic acid and 0.001 M L-cystine per litre of distilled water, adjusted to $\mathrm{pH}$ 7.2) using a pre-cooled sterilized mortar and pestle (Adamu et al., 2015). Two microlitres of $\beta$ mercapto-ethanol was added to the extract prior to application. The upper leaf surface of the target plants were dusted with 600-mesh carborundum (Fisher Scientific, Fair Lawn, NJ) powder before the inoculum extract was applied. The inoculated leaves were then rinsed with cold distilled water and observed for disease symptoms. The infected leaves were harvested at three weeks after inoculation (WAI). Leaf tissues infected with CABMV were preserved in vials $(1 \mathrm{~g}$ of the leaf/vial) at room temperature. Each vial contained $5 \mathrm{~g}$ silica gel as moisture absorber covered with $1 \mathrm{~g}$ of non-absorbent cotton wool.

\section{Field Establishment, Inoculation and Crop} Management

The experimental site was ploughed with tractor in the first week of May, 2016. Manual ridging was then carried out at one week after ploughing. Groundnut seeds were sown in the second week of 
May, 2016 on the ridges at the rate of two seeds per hole, using $75 \mathrm{~cm} \times 25 \mathrm{~cm}$ inter- and intra row spacing. Seedlings were thinned to one plant per stand at one week after emergence. Manual weeding was carried out at 3,5 and 8 weeks after planting. The earlier preserved virus isolates (CABMV infected leaves) were used to inoculate the treatment plots on the field. Inoculation was carried out following the same procedure as described above. Lambda cyhalothrin $30 \%$ EC insecticide was sprayed (Badii et al., 2013) at the rate of 2.5 litres/ha in three applications to control aphids and other insects. Insecticide was applied weekly starting from 2 weeks after sowing (WAS) until the fourth week.

\section{Data Collection and Statistical Analysis}

Disease incidence was recorded at 1 and 2 weeks after inoculation (WAI). It was taken as percentage of the total plants that exhibited symptoms of CABMV disease. Disease symptoms were scored using a scale of 1-5 (Adamu et al., 2015) as follows:

$1=$ no symptoms (apparently healthy plant)

$2=$ mild mosaic $(10-30 \%$ infection $)$

$3=$ moderate mosaic (31-50\% infection)

$4=$ severe mosaic, chlorosis and stunting (51-70\% infection)

$5=$ very severe mosaic, chlorosis, stunting and plant dead (>70\% infection)

The growth and yield parameters observed were plant height $(\mathrm{cm})$, leaf diameter $(\mathrm{cm})$, number of branches per plant, number of days to $50 \%$ flowering, number of pod per plant, pod weight per plant $(\mathrm{g})$, fresh haulm weight per plant $(\mathrm{g})$, dry haulm weight per plant $(\mathrm{g}), 100$-seed weight $(\mathrm{g})$ and pod yield $\left(\mathrm{kg} \mathrm{ha}^{-1}\right)$. The data were subjected to analysis of variance, principal component and cluster analyses, using Statistical Analysis System (SAS, 2008). The cultivars were classified into three clusters based on the reductions in their growth and yield parameters using Unweighted Pair Group Method with Arithmetic (UPGMA) mean (Adama et al., 2015).

Reduction $(\%)=\left(\mathrm{X}_{1}-\mathrm{X}_{2}\right) \times 100$;

where $X_{1}$ is mean of healthy plants and $X_{2}$ is mean of infected plants.

\section{RESULTS}

CABMV Disease Incidence and Effects on Growth Characters

All the inoculated plants showed disease symptoms at 1 WAI. The symptoms observed varied from mild to severe mosaic. Generally, the healthy plants were significantly $(p<0.05)$ taller than infected plants with the exception of "SAMNUT 14" (Table 1). The highest height reduction was observed in "ICG-94169" (59.1\%) followed by "SAMNUT 21" and "ICG-01276" which showed 45 and 44.3 $\%$ height reduction, respectively. The groundnut cultivars "FDRF7-61", "ICG-02189", "ICG-5195", "ICG-IS-13986", "ICGV-91317”, "ICGV-IS76855", "SAMNUT 22", and "SAMNUT 24" exhibited height reduction between 30 and $39 \%$. Other cultivars such as "FDRF7-67", "ICG92267", "ICG-IS-13003", “SAMNUT 10", "SAMNUT 23" and "SAMNUT 26" suffered between 22.2 and $29.6 \%$ height reduction. Height reduction of $14.8 \%$ was observed in "ICG-6654", whereas the height of "SAMNUT 14" and "SAMNUT 25" was reduced by 7.8 and $10.8 \%$, respectively.

The leaf diameter of healthy plants was significantly $(p<0.05)$ wider than their infected counterparts (Table 1). The cultivar "SAMNUT 25 " had the highest reduction in leaf diameter (35.9 $\%)$. In seven other cultivars ("ICG-02189", "ICG5195", "ICG-92267", "ICGV-91317”, "SAMNUT 21", "SAMNUT 22" and "SAMNUT 24") leaf diameter reduction was greater than $30 \%$. Reduction between 20.4 and $29.7 \%$ in leaf diameter was observed in "FDRF7-61", "ICG01276", "ICG-IS- 13003", "ICG-IS-13986", "ICGV-IS-76855", "SAMNUT 10", "SAMNUT 23 " and "SAMNUT 26". On the other hand, the cultivars "FDRF7-67", "ICG-6654", "ICG-94169" and "SAMNUT 14" suffered between 13.4 and $17.9 \%$ reduction in leaf diameter. All the healthy plants except in "FDRF7-67", "ICG-6654" and "SAMNUT 23" produced significantly $(p<0.05)$ higher number of branches compared to the infected ones (Table 1). The highest reduction in number of branches per plant was observed in "ICG-92267" (68.0\%) followed by "ICGV-91317" (66.7 \%), "SAMNUT 21" (60.9\%) and "SAMNUT 25 " $(60.0 \%)$. In "ICG-02189”, "ICG-5195”, "ICG94169”, "ICGV-IS-76855”, “SAMNUT 10”, "SAMNUT 14", "SAMNUT 23" and "SAMNUT 23 " reduction in number of branches per plant ranged between 50 and $58.8 \%$. Five cultivars ("FDRF7-61", "ICG-01276", "ICG-IS-13986", "SAMNUT 22" and "SAMNUT 26") showed reduction which varied from 40 to $47.6 \%$. Number of branches per plant was reduced by $33.3 \%$ in "FDRF7-67" and "ICG-6654", whereas the lowest reduction in number of branches was observed in "ICG-IS-13003" (30.8\%) 


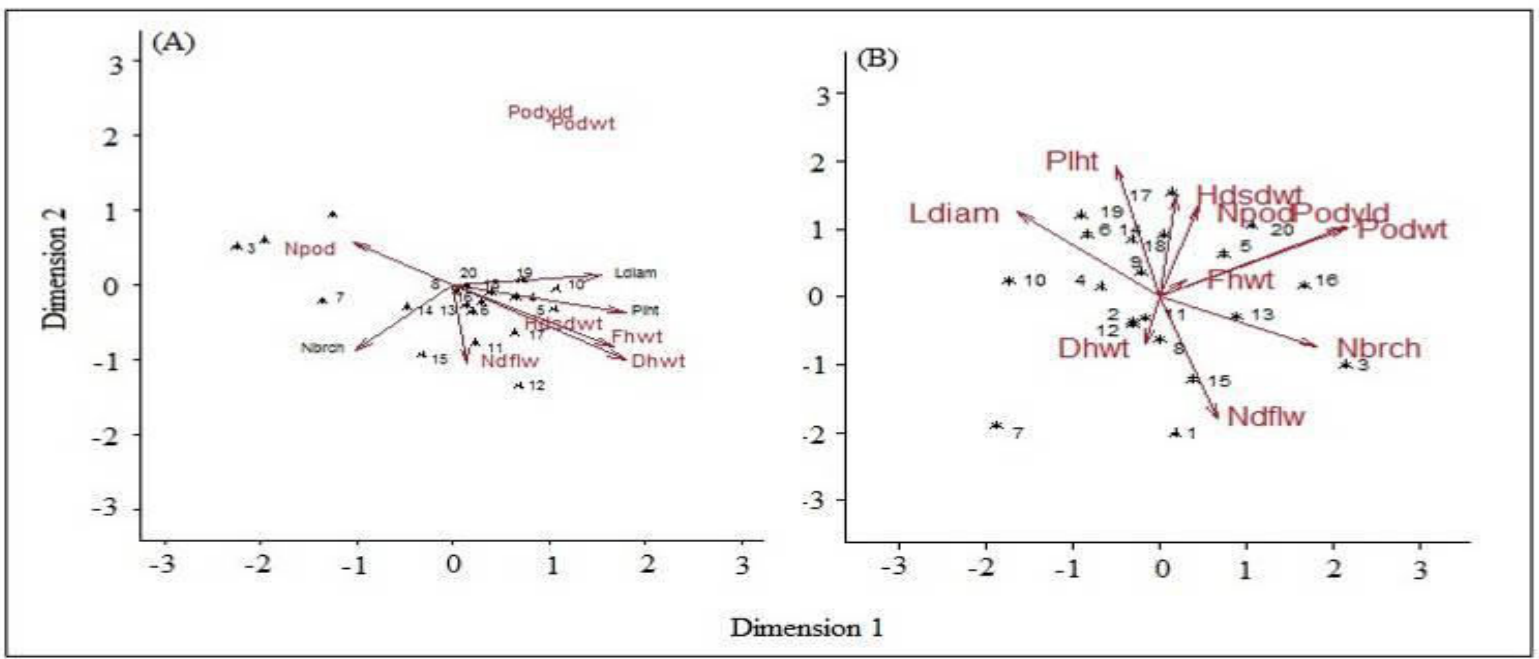

Figure 1: Biplot of the first two principal components from (A) Healthy and (B) Cowpea aphid-borne mosaic virus infected groundnut plants

Table 1: Mean plant height $(\mathrm{cm})$, leaf diameter $(\mathrm{cm})$ and number of branches per plant in Cowpea aphid-borne mosaic virus infected compared with healthy groundnut plants

\begin{tabular}{|c|c|c|c|c|c|c|c|c|c|c|c|c|}
\hline \multirow[b]{3}{*}{ Cultivar } & \multicolumn{4}{|c|}{ Plant height $(\mathrm{cm})$} & \multicolumn{4}{|c|}{ Leaf diameter $(\mathrm{cm})$} & \multicolumn{4}{|c|}{ Number of branches per plant } \\
\hline & & & & $\%$ & & & & $\%$ & & & & $\%$ \\
\hline & Healthy & Infected & LSD & Reduction & Healthy & Infected & LSD & Reduction & Healthy & Infected & LSD & Reduction \\
\hline FDRF7-61 & 32.8 & 21.2 & 4.5 & 35.5 & 2.6 & 1.8 & 0.3 & 28.8 & 16 & 9 & 1.9 & 43.8 \\
\hline FDRF7-67 & 36.4 & 28.1 & 2.7 & 22.8 & 2.5 & 2.2 & 0.3 & 14.2 & 12 & 8 & 1.0 & 33.3 \\
\hline ICG-01276 & 37.1 & 20.7 & 4.8 & 44.3 & 2.4 & 1.7 & 0.3 & 28.8 & 21 & 11 & 3.3 & 47.6 \\
\hline ICG-02189 & 40.1 & 27.4 & 2.7 & 31.7 & 3.2 & 2.1 & 0.3 & 34.1 & 16 & 8 & 1.4 & 50.0 \\
\hline ICG-5195 & 51.4 & 32.2 & 3.3 & 37.3 & 3.2 & 2.2 & 0.3 & 32.8 & 19 & 9 & 2.0 & 52.6 \\
\hline ICG-6654 & 38.8 & 33.0 & 3.0 & 14.8 & 2.8 & 2.4 & 0.0 & 13.4 & 12 & 8 & 2.6 & 33.3 \\
\hline ICG-92267 & 31.4 & 23.2 & 1.2 & 26.2 & 3.3 & 2.2 & 0.3 & 31.8 & 25 & 8 & 4.5 & 68.0 \\
\hline ICG-94169 & 39.2 & 16.0 & 2.7 & 59.1 & 2.8 & 2.3 & 0.3 & 17.9 & 17 & 8 & 2.5 & 52.9 \\
\hline ICG-IS- 13003 & 38.8 & 27.3 & 2.1 & 29.6 & 3.1 & 2.2 & 0.3 & 29.7 & 13 & 9 & 2.6 & 30.8 \\
\hline ICG-IS- 13986 & 46.0 & 28.1 & 2.1 & 39.0 & 3.1 & 2.4 & 0.3 & 24.3 & 10 & 6 & 1.4 & 40.0 \\
\hline ICGV-91317 & 41.5 & 28.3 & 2.4 & 31.8 & 3.1 & 2.0 & 0.3 & 33.9 & 18 & 6 & 3.9 & 66.7 \\
\hline ICGV-IS-76855 & 40.5 & 25.8 & 2.4 & 36.3 & 2.7 & 2.1 & 0.3 & 20.4 & 17 & 7 & 1.7 & 58.8 \\
\hline SAMNUT 10 & 38.5 & 27.7 & 2.7 & 28.0 & 3.0 & 2.1 & 0.6 & 29.0 & 18 & 9 & 2.0 & 50.0 \\
\hline SAMNUT 14 & 38.1 & 35.1 & 3.0 & 7.8 & 2.6 & 2.2 & 0.6 & 16.4 & 18 & 9 & 2.6 & 50.0 \\
\hline SAMNUT 21 & 35.5 & 19.5 & 3.9 & 45.0 & 2.7 & 1.9 & 0.3 & 31.5 & 23 & 9 & 5.6 & 60.9 \\
\hline SAMNUT 22 & 40.9 & 27.0 & 4.2 & 34.1 & 3.1 & 2.0 & 0.3 & 35.1 & 20 & 11 & 2.2 & 45.0 \\
\hline SAMNUT 23 & 40.2 & 29.1 & 2.4 & 27.6 & 2.8 & 2.2 & 0.6 & 21.4 & 14 & 7 & 2.0 & 50.0 \\
\hline SAMNUT 24 & 43.0 & 28.4 & 5.1 & 33.8 & 3.2 & 2.1 & 0.3 & 32.8 & 14 & 7 & 3.7 & 50.0 \\
\hline SAMNUT 25 & 42.4 & 37.8 & 2.4 & 10.8 & 3.4 & 2.2 & 0.3 & 35.9 & 15 & 6 & 3.7 & 60.0 \\
\hline SAMNUT 26 & 37.9 & 29.5 & 6.6 & 22.2 & 2.9 & 2.1 & 0.3 & 27.9 & 15 & 9 & 1.0 & 40.0 \\
\hline
\end{tabular}

For each cultivar, means of healthy and infected plants were compared along the row using the Least Significant Difference (LSD) at $p \leq 0.05$

\section{Effects of CABMV Infection on Reproductive Characters}

Cowpea aphid-borne mosaic virus disease delayed the number of days to $50 \%$ flowering in almost all the infected groundnut cultivars even though the effect was in most cases not significant $(p>0.05)$ (Table 2). Majority of the infected plants attained $50 \%$ flowering at 1 or 2 days later than their healthy counterparts. "SAMNUT 10" was most affected with $50 \%$ flowering being delayed for 5 days. Next to it were "ICG-92267" and "SAMNUT 21 " in which $50 \%$ flowering was delayed for 3 days. Conversely, the infected plants of "ICG-IS13986", "SAMNUT 23" and "SAMNUT 26" attained $50 \%$ flowering concurrently with their healthy plants. The healthy plants produced significantly $(p<0.05)$ higher number of pods per plant than the infected plants (Table 2). Reduction in pod number was highest in "ICG-94169" (78.6
$\%)$, followed by "ICG-92267" (60.9 \%). The lowest reduction in number of pods per plant was found in "SAMNUT 23" (4.3\%). However, relatively low reduction was also observed in "ICG-6654" (8.7 \%), "ICGV-91317" (13 \%), "ICGV-IS-76855" (5\%) and "SAMNUT 24" (6.9 $\%)$. In the remaining cultivars, pod number was reduced by a range of 25 to $54.8 \%$. Generally, pod weight per plant was significantly $(p<0.05)$ higher in the healthy plants than their infected counterparts (Table 2). The healthy plants exhibited pod weight that varied between 14.3 in "ICG92267" and $22.3 \mathrm{~g}$ in "ICG-IS-13003" per plant. Conversely, a range of 5 ("ICG-92267") to $6.2 \mathrm{~g}$ ("SAMNUT26") was observed in the infected plants. Also, most of the infected plants suffered more than $60.0 \%$ reduction in pod weight. The highest pod weight reduction was observed in "ICG-IS- 13003" (74.6\%) while the lowest was 
found in "SAMNUT 23" (59.1\%). Other cultivars such as "ICG-01276", "SAMNUT 10", "SAMNUT 22" and "SAMNUT 26" had between 59.2 and 59.7 $\%$ reduction in pod weight per plant. Fresh haulm weight per plant varied between 75.8 ("ICG92267") and 153.2 g ("ICG-02189") per plant in the healthy plants, whereas a range of 26.2 ("ICGV-91317") to $48.7 \mathrm{~g}$ ("FDR7-67") was found in the infected plants (Table 3). Fresh haulm weight per plant of most infected plants was significantly $(p<0.05)$ reduced by CABMV disease. "ICG02189 " with $80.7 \%$ suffered the highest reduction among the infected plants while only "FDRF7-67" $(46.4 \%)$ exhibited less than $50 \%$ reduction in fresh haulm weight per plant. The healthy plants produced dry haulm weight varying between 25.2 ("ICG-01276") and $60.3 \mathrm{~g}$ ("SAMNUT21") per plant (Table 3). On the other hand, the infected plants had dry haulm weight between 13.6 ("ICG02189") and 24 g ("ICG-92267") per plant. Majority of the infected plants suffered between 60.2 ("SAMNUT 23") and $74.9 \%$ ("ICG-02189") reduction in dry weight per plant. The cultivars "FDR7-61", "ICG-92267", "ICG-IS-13986", "ICGV-91317" and "SAMNUT 22" exhibited between 49.5 and $59.5 \%$ reduction in dry haulm weight per plant. FDR7-67 had $36.4 \%$ reduction in dry haulm weight while "ICG-01276" exhibited the lowest $(17.5 \%)$.

Table 2: Mean number of days to $50 \%$ flowering, pods per plant (no.), and pod weight per plant (g) in Cowpea aphid-borne mosaic virus infected compared with healthy groundnut plants

\begin{tabular}{|c|c|c|c|c|c|c|c|c|c|c|c|c|}
\hline \multirow[b]{2}{*}{ Cultivar } & \multicolumn{4}{|c|}{ Days to $50 \%$ flowering (no.) } & \multicolumn{4}{|c|}{ Pods per plant (no.)\% } & \multicolumn{4}{|c|}{ Pod weight per plant (g)\% } \\
\hline & Healthy & Infected & LSD & Increase & Healthy & Infected & LSD & Reduction & Healthy & Infected & LSD & Reduction \\
\hline FDRF7-61 & 31 & 33 & 2.4 & 2 & 29 & 15 & 5.1 & 48.3 & 14.6 & 5.4 & 0.9 & 62.8 \\
\hline FDRF7-67 & 29 & 31 & 1.5 & 2 & 27 & 14 & 3.3 & 48.1 & 15.1 & 5.6 & 0.6 & 62.8 \\
\hline ICG-02189 & 29 & 31 & 0.9 & 2 & 31 & 14 & 10.7 & 54.8 & 14.9 & 5.5 & 0.4 & 62.9 \\
\hline ICG-5195 & 30 & 32 & 0.9 & 2 & 25 & 18 & 3.7 & 28.0 & 15.3 & 6.1 & 0.3 & 60.1 \\
\hline ICG-6654 & 30 & 32 & 1.5 & 2 & 23 & 21 & 8.1 & 8.7 & 14.4 & 5.5 & 0.5 & 61.7 \\
\hline ICG-92267 & 30 & 33 & 0.9 & 3 & 23 & 9 & 3.3 & 60.9 & 14.3 & 5.0 & 0.4 & 65.1 \\
\hline ICG-IS- 13003 & 30 & 31 & 0.9 & 1 & 24 & 17 & 14.8 & 29.2 & 22.3 & 5.7 & 1.6 & 74.6 \\
\hline ICG-IS- 13986 & 31 & 31 & 0.9 & 0 & 24 & 18 & 2.3 & 25.0 & 15 & 5.3 & 0.6 & 64.7 \\
\hline ICGV-91317 & 34 & 35 & 0.9 & 1 & 23 & 20 & 9.6 & 13.0 & 14.9 & 5.8 & 0.3 & 61.2 \\
\hline ICGV-IS-76855 & 35 & 36 & 0.9 & 1 & 20 & 19 & 4.4 & 5.0 & 14.7 & 5.5 & 0.5 & 62.5 \\
\hline SAMNUT 10 & 30 & 35 & 0.9 & 5 & 27 & 15 & 6.1 & 44.4 & 14.8 & 6.0 & 0.6 & 59.7 \\
\hline SAMNUT 14 & 30 & 31 & 1.5 & 1 & 29 & 21 & 3.9 & 27.6 & 14.6 & 5.8 & 0.5 & 60.4 \\
\hline SAMNUT 21 & 32 & 35 & 0.6 & 3 & 26 & 16 & 2.7 & 38.5 & 14.7 & 5.5 & 0.5 & 62.5 \\
\hline SAMNUT 22 & 30 & 33 & 1.2 & 2 & 25 & 18 & 6.2 & 28.0 & 15 & 6.1 & 0.3 & 59.2 \\
\hline SAMNUT 24 & 30 & 31 & 0.9 & 1 & 29 & 27 & 12.4 & 6.9 & 14.7 & 5.6 & 0.8 & 61.7 \\
\hline SAMNUT 25 & 30 & 31 & 0.9 & 1 & 26 & 16 & 5.1 & 38.5 & 15.1 & 5.6 & 0.4 & 62.9 \\
\hline SAMNUT 26 & 31 & 31 & 1.5 & 0 & & 16 & 4.2 & 38.5 & 15.3 & 6.2 & 0.4 & 59.6 \\
\hline
\end{tabular}

For each cultivar, means of healthy and infected plants were compared along the row using the Least Significant Difference (LSD) at $p \leq 0.05$

Table 3: Mean fresh and dry haulm weight per plant (g) of Cowpea aphid-borne mosaic virus infected compared with healthy groundnut plants

\begin{tabular}{|c|c|c|c|c|c|c|c|c|}
\hline \multirow[b]{2}{*}{ Cultivar } & \multicolumn{4}{|c|}{ Fresh haulm weight per plant (g) } & \multicolumn{4}{|c|}{ Dry haulm weight per plant (g) } \\
\hline & Healthy & Infected & LSD & $\begin{array}{c}\% \\
\text { Reduction }\end{array}$ & Healthy & Infected & LSD & $\begin{array}{c}\% \\
\text { Reduction }\end{array}$ \\
\hline FDR7-61 & 87.3 & 38.9 & 10.2 & 55.5 & 40 & 20.2 & 6.9 & 49.5 \\
\hline FDR7-67 & 90.9 & 48.7 & 15.3 & 46.4 & 35.2 & 22.4 & 7.3 & 36.4 \\
\hline ICG-01276 & 91.1 & 40.9 & 10.5 & 55.1 & 25.2 & 20.8 & 8.6 & 17.5 \\
\hline ICG-02189 & 153.2 & 29.5 & 44.1 & 80.7 & 54.2 & 13.6 & 5.7 & 74.9 \\
\hline ICG-5195 & 124.6 & 43.7 & 21.0 & 64.9 & 55.3 & 21.1 & 13.0 & 61.9 \\
\hline ICG-6654 & 117.7 & 35.3 & 21.0 & 70.0 & 53.8 & 14.9 & 13.0 & 72.2 \\
\hline ICG-92267 & 75.8 & 33.2 & 72.3 & 56.2 & 50.7 & 24.0 & 14.2 & 52.7 \\
\hline ICG-94169 & 111.7 & 36.8 & 6.0 & 67.1 & 50.7 & 17.2 & 2.3 & 66.1 \\
\hline ICG-IS- 13003 & 104.3 & 37.8 & 10.5 & 63.7 & 51.4 & 19.8 & 5.6 & 61.4 \\
\hline ICG-IS- 13986 & 116.4 & 41.9 & 21.0 & 64.0 & 54.2 & 23.3 & 11.6 & 57.1 \\
\hline ICGV-91317 & 110.4 & 26.2 & 20.1 & 76.2 & 53.4 & 23.0 & 20.5 & 56.8 \\
\hline ICGV-IS-76855 & 122.3 & 39.9 & 18.0 & 67.4 & 60.3 & 20.2 & 8.3 & 66.6 \\
\hline SAMNUT10 & 119.9 & 35.5 & 11.1 & 70.4 & 59.5 & 18.5 & 3.3 & 68.9 \\
\hline SAMNUT14 & 114.8 & 40.7 & 15.9 & 64.5 & 59.3 & 20.0 & 6.1 & 66.2 \\
\hline SAMNUT21 & 117.2 & 38.4 & 10.5 & 67.2 & 60.3 & 20.0 & 5.4 & 66.8 \\
\hline SAMNUT22 & 109.3 & 40.9 & 13.5 & 62.6 & 55.4 & 22.4 & 6.3 & 59.5 \\
\hline SAMNUT23 & 118.8 & 41.9 & 21.9 & 64.7 & 53.5 & 21.3 & 3.3 & 60.2 \\
\hline SAMNUT24 & 109.9 & 36.8 & 8.7 & 66.5 & 59.3 & 19.2 & 8.7 & 67.6 \\
\hline SAMNUT25 & 102.7 & 41.4 & 7.8 & 59.7 & 53.1 & 20.0 & 6.5 & 62.3 \\
\hline SAMNUT26 & 107.9 & 31.5 & 6.9 & 70.8 & 55.3 & 17.1 & 4.7 & 69.0 \\
\hline
\end{tabular}

For each cultivar, means of healthy and infected plants were compared along the row using the Least Significant Difference (LSD) at $p \leq 0.05$ 
One hundred-seed weight of the healthy plants significantly $(p<0.05)$ outweighed their infected counterparts particularly in "FDRF7-67", "ICG02189”, "ICG-94169”, “ICG-IS-13003”, “ ICGVIS-13986", "ICGV-IS-76855", "SAMNUT 10", "SAMNUT 14", "SAMNUT 21", "SAMNUT 22", "SAMNUT 23", "SAMNUT 25" and "SAMNUT 26" (Table 4). The lowest reduction in 100-seed weight was found in "ICG-5195" (8.1\%). Other cultivars which exhibited relatively low reduction in 100-seed weight were "ICG-6654" (9.5\%), "SAMNUT 24" (12\%), "SAMNUT 26" (13.1\%), "SAMNUT 21" (13.4\%), "SAMNUT 25" (13.6 $\%)$, "ICGV-IS-76855" (14.7 \%), "ICG-IS-13986" (16\%), "ICG-IS-13003” (16.4\%), "SAMNUT 14" (16.8\%), "ICGV-91317" (17.1\%), "SAMNUT 23 " (17.3\%), "SAMNUT 22" (17.6\%), "ICG92267" (18.1\%) and "ICG-01276" (18.5\%). The remaining cultivars had between 20.3 ("SAMNUT10") and $50.9 \%$ ("FDR7-67") reduction in 100-seed weight. All uninoculated plants produced significantly $(p<0.05)$ higher pod yield compared to the diseased plants. The healthy plants of "ICG-IS-13003" produced 1, $490 \mathrm{~kg}$ of pods per hectare while other cultivars produced a range of $970-1,020 \mathrm{~kg} \mathrm{ha}^{-1}$. On the other hand, the infected plants produced between 330 and $410 \mathrm{~kg}$ of pods per hectare. The highest reduction in pod yield $(74.5 \%)$ was observed in "ICG-IS-13003", whereas "SAMNUT 23" had the lowest (58.8\%) reduction in pod yield. The remaining cultivars exhibited between 59.0 and $65.6 \%$ reduction in pod yield.

\section{Principal Component Analysis Based on Growth and Yield Traits}

The first five principal components of healthy plants accounted for $83.8 \%$ of the total variation (Table 5). The PC 1 was strongly correlated with dry haulm weight per plant (eigen vector $=0.4388$ ), plant height (eigen vector $=0.4386$ ) and fresh haulm weight per plant (eigen vector $=0.4089$ ). The PC 2 was loaded with pod yield (eigen vector $=0.5899$ ) and pod weight per plant (eigen vector $=$ 0.5894). The third principal component was mainly loaded with number of days to $50 \%$ flowering (eigen vector $=0.6094$ ) while variability in PC 4 was mainly due to the number of branches per plant (eigen vector $=0.5861$ ) and leaf diameter (eigen vector $=0.5599$. The fifth principal component was positively correlated with 100-seed weight (eigen vector $=0.6329)$. Leaf diameter, number of pods per plant, pod weight per plant and pod yield contributed positively to the variability among "ICG-01276", "ICG-92267", "ICG-IS-13986", "SAMNUT 25" and "SAMNUT 26" (Figure 1 A).

The first five principal components of the infected groundnut plants accounted for $85.4 \%$ of the total variation (Table 5). The PC 1 was loaded with pod yield (eigen vector $=0.5358$ ), pod weight per plant (eigen vector $=0.5304$ ) and number of branches per plant (eigen vector $=0.4502$ ). Variability in the PC 2 was induced by plant height (eigen vector $=0.4883$ ) while in PC 3 , fresh haulm weight per plant (eigen vector $=0.6555$ ) and dry haulm weight per plant (eigen vector $=0.6270$ ) were responsible for the observed variability.

Table 4: Mean 100-seed weight per plant and pod yield $\left(\mathrm{kg} \mathrm{ha}^{-1}\right)$ of Cowpea aphid-borne mosaic virus infected compared with healthy groundnut plants

\begin{tabular}{|c|c|c|c|c|c|c|c|c|}
\hline \multirow[b]{2}{*}{ Cultivar } & \multicolumn{4}{|c|}{100 -seed weight per plant $(\mathrm{g})$} & \multicolumn{4}{|c|}{ Pod yield $\left(\mathrm{kg} \mathrm{ha}^{-1}\right) \%$} \\
\hline & Healthy & Infected & LSD & $\%$ Reduction & Healthy & Infected & LSD & Reduction \\
\hline FDR7-61 & 34.7 & 27.4 & 5.1 & 21.1 & 970 & 360 & 0.057 & 62.9 \\
\hline FDR7-67 & 51.1 & 25.1 & 11.9 & 50.9 & 1010 & 380 & 0.040 & 62.4 \\
\hline ICG-01276 & 41.7 & 34.0 & 4.0 & 18.5 & 1000 & 400 & 0.019 & 60.0 \\
\hline ICG-02189 & 48.4 & 37.9 & 4.3 & 21.7 & 990 & 370 & 0.031 & 62.6 \\
\hline ICG-5195 & 40.3 & 37.0 & 4.5 & 8.1 & 1020 & 400 & 0.020 & 60.8 \\
\hline ICG-6654 & 46.1 & 41.7 & 6.9 & 9.5 & 960 & 370 & 0.032 & 61.5 \\
\hline ICG-92267 & 38.8 & 31.8 & 5.8 & 18.1 & 960 & 330 & 0.023 & 65.6 \\
\hline ICG-94169 & 65.0 & 42.7 & 7.7 & 34.3 & 1000 & 390 & 0.051 & 61.0 \\
\hline ICG-IS- 13003 & 50.5 & 42.2 & 5.6 & 16.4 & 1490 & 380 & 1.043 & 74.5 \\
\hline ICG-IS- 13986 & 50.4 & 42.4 & 2.2 & 16.0 & 1000 & 350 & 0.044 & 65.0 \\
\hline ICGV-91317 & 43.1 & 35.7 & 8.4 & 17.1 & 990 & 390 & 0.020 & 60.6 \\
\hline ICGV-IS-76855 & 54.9 & 46.8 & 6.6 & 14.7 & 980 & 360 & 0.038 & 63.3 \\
\hline SAMNUT10 & 49.6 & 39.6 & 9.9 & 20.3 & 990 & 400 & 0.042 & 59.6 \\
\hline SAMNUT14 & 43.6 & 36.3 & 4.0 & 16.8 & 980 & 390 & 0.038 & 60.2 \\
\hline SAMNUT21 & 54.2 & 46.9 & 6.3 & 13.4 & 980 & 370 & 0.035 & 62.2 \\
\hline SAMNUT22 & 55.1 & 45.4 & 7.4 & 17.6 & 1000 & 410 & 0.019 & 59.0 \\
\hline SAMNUT23 & 67.7 & 56.0 & 5.1 & 17.3 & 970 & 400 & 0.044 & 58.8 \\
\hline SAMNUT24 & 46.0 & 40.5 & 3.9 & 12.0 & 980 & 380 & 0.053 & 61.2 \\
\hline SAMNUT25 & 58.4 & 50.5 & 4.2 & 13.6 & 1010 & 370 & 0.029 & 63.4 \\
\hline SAMNUT26 & 58.6 & 50.9 & 4.4 & 13.1 & 1020 & 410 & 0.027 & 59.8 \\
\hline
\end{tabular}

For each cultivar, means of healthy and infected plants were compared along the row using the Least Significant Difference (LSD) at $p \leq 0.05$ 
Table 5: Eigen vectors from the principal components (PCs) of growth and yield attributes in healthy and Cowpea aphid-borne mosaic virus infected groundnut plants

\begin{tabular}{|c|c|c|c|c|c|c|c|c|c|c|}
\hline & & & Healthy & & & & & Infected & & \\
\hline Plant trait & PC 1 & PC 2 & PC 3 & $\mathrm{PC} 4$ & PC 5 & PC 1 & PC 2 & PC 3 & PC 4 & PC 5 \\
\hline Plant height $(\mathrm{cm})$ & 0.4386 & -0.1009 & -0.2133 & -0.0046 & -0.5350 & -0.1250 & 0.4883 & 0.1922 & 0.0235 & -0.3281 \\
\hline Leaf diameter $(\mathrm{cm})$ & 0.3792 & 0.0324 & -0.2043 & 0.5599 & 0.0984 & -0.4047 & 0.3137 & -0.0524 & -0.3272 & 0.2194 \\
\hline Number of branches per plant & -0.2514 & -0.2388 & 0.1745 & 0.5861 & 0.3120 & 0.4502 & -0.1842 & 0.0737 & -0.3830 & -0.2279 \\
\hline Number of days to flowering & 0.0359 & -0.2839 & 0.6094 & -0.0113 & -0.3293 & 0.1636 & -0.4522 & -0.0854 & 0.4099 & 0.1285 \\
\hline Fresh haulm weight per plant $(\mathrm{g})$ & 0.4089 & -0.2256 & -0.2510 & -0.1570 & -0.0069 & 0.0790 & 0.0655 & 0.6555 & -0.2969 & 0.2971 \\
\hline Dry haulm weight per plant (g) & 0.4388 & -0.2723 & 0.0303 & 0.2291 & 0.2900 & -0.0382 & -0.1736 & 0.6270 & 0.2891 & 0.2865 \\
\hline Number of pods per plant & -0.2576 & 0.1541 & -0.5788 & -0.0086 & 0.1076 & 0.1123 & 0.3385 & 0.2456 & 0.5307 & -0.4591 \\
\hline Pod weight per plant (g) & 0.2181 & 0.5894 & 0.2147 & 0.0865 & 0.0326 & 0.5304 & 0.2640 & -0.0508 & -0.0732 & 0.1382 \\
\hline Pod yield $\left(\mathrm{kg} \mathrm{ha}^{-1}\right)$ & 0.2176 & 0.5899 & 0.2135 & 0.0912 & 0.0309 & 0.5358 & 0.2546 & -0.0614 & -0.0510 & 0.1220 \\
\hline 100 -seed weight $(\mathrm{g})$ & 0.2798 & -0.0834 & 0.1428 & -0.4998 & 0.6329 & 0.0495 & 0.3758 & -0.2411 & 0.3413 & 0.6005 \\
\hline$\%$ variation & 26.6 & 21.8 & 15.4 & 11.6 & 8.4 & 26.3 & 25.2 & 14.8 & 10.9 & 8.2 \\
\hline Cumulative variation & 26.6 & 48.4 & 63.8 & 75.4 & 83.8 & 26.3 & 51.5 & 66.3 & 77.2 & 85.4 \\
\hline
\end{tabular}

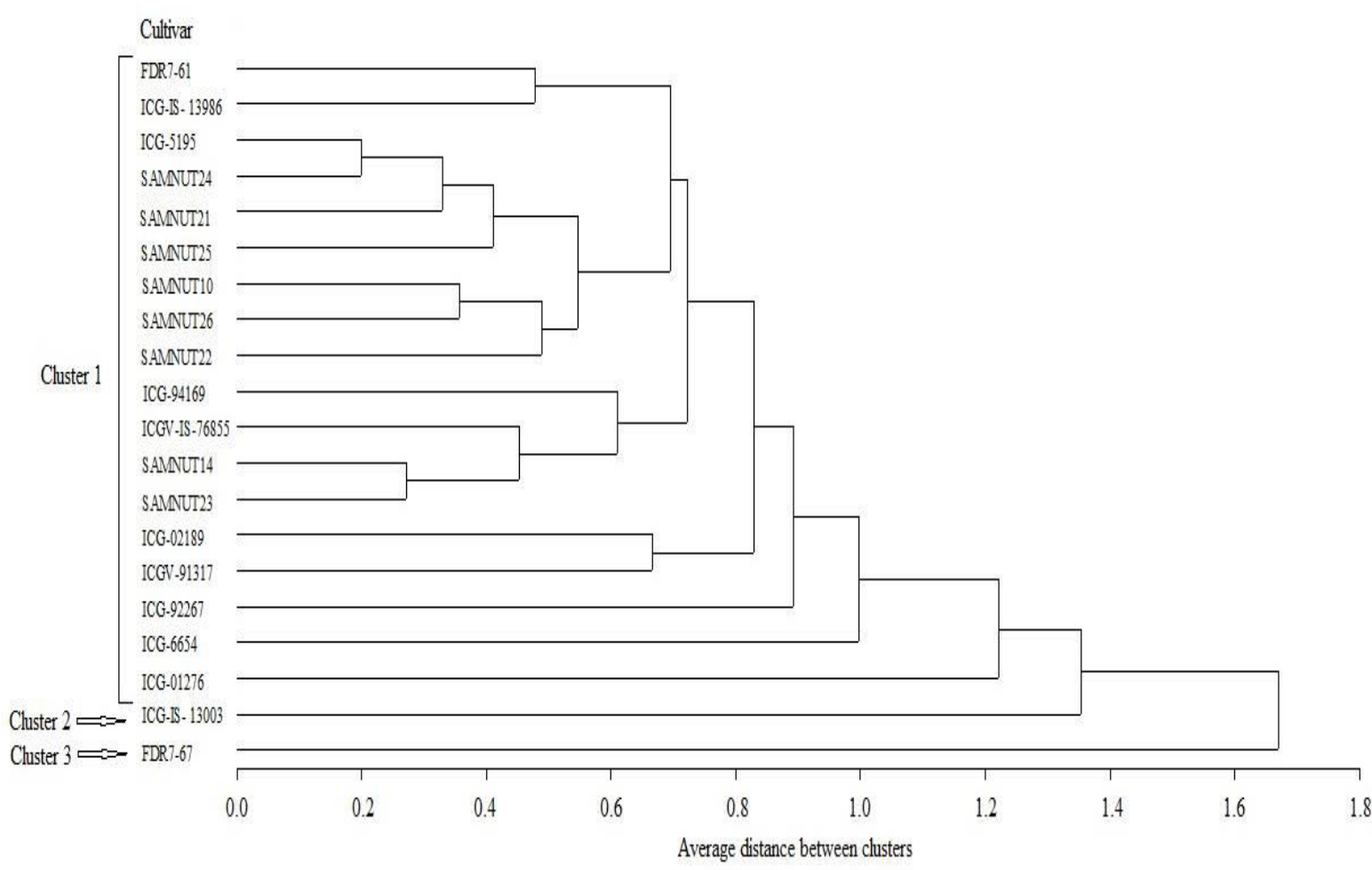

Figure 2: Dendogram of the reduction in growth and yield attributes of groundnut cultivars infected with Cowpea aphid-borne mosaic virus, according to Unweighted Pair Group Method with Arithmetic (UPGMA) mean

The fourth principal component was positively correlated with number of pods per plant (eigen vector $=0.5307)$ and number of days to $50 \%$ flowering (eigen vector $=0.4099$ ). On the other hand, the PC 5 was majorly loaded with 100 -seed weight (eigen vector $=0.6005)$. Plant height, leaf diameter, fresh haulm weight per plant, pod weight per plant, pod yield and 100-seed weight exerted positive contribution to the variability among "ICG-02189", "ICG-5195", "ICG-6654", "ICG94169", "ICG-IS-13003", “ICG-IS-13986", "SAMNUT 14", "SAMNUT 22", "SAMNUT 23", "SAMNUT 25" and "SAMNUT 26" (Figure 1 B).
Groundnut cultivar: 1 = "FDRF7-61", 2 = "FDRF7-67", 3 = "ICG-01276", 4 = "ICG-02189", 5 = "ICG-5159", 6 = "ICG-6654", 7 = "ICG92267", 8 = "ICG-94169", 9 = "ICG-IS-13003", 10 = "ICG-IS-13986", 11 = "ICGV-91317", 12 = "ICGV-IS-76855", 13 = "SAMNUT 10", 14 = "SAMNUT 14", 15 = "SAMNUT 21", $16=$ "SAMNUT 22", 17 = "SAMNUT 23", 18 = "SAMNUT 24", 19 = "SAMNUT 25", $20=$ "SAMNUT 26"

Plant character: Plht $=$ Plant height, Ldiam $=$ Leaf diameter, Nbrch $=$ Number of branches per plant, Ndflw $=$ Number of days to $50 \%$ flowering, Fhwt 
$=$ Fresh haulm weight per plant, Dhwt $=$ Dry haulm weight per plant, Npod $=$ Number of pods per plant, Podwt $=$ Pod weight per plant, Hdsdwt $=$ 100-seed weight, Podyld $=$ Pod yield Cluster analysis showed that eighteen cultivars ("FDRF761", "ICG-IS-13986", "ICG-5195", "SAMNUT 24", "SAMNUT 21", "SAMNUT 25", "SAMNUT 10", "SAMNUT 26", "SAMNUT 22", "ICG94169”, “ICGV-IS-76855", “SAMNUT 14”, "SAMNUT 23", "ICG-02189", "ICGV-91317", "ICG-92267", "ICG-6654" and "ICG-01276") belonged to cluster 1 (Figure 2). Cultivars in this cluster exhibited variable reduction in height $(7.8$ to $59.1 \%$ ), leaf diameter (13.4 to $35.9 \%$ ), number of branches (33.3 to $68.0 \%$ ), increased days to 50 $\%$ flowering ( 0 to 5 days), reduction in number of pods per plant (4.3 to $78.6 \%$ ), pod weight per plant (59.1 to $65.1 \%)$, fresh haulm weight per plant (55.1 to $80.7 \%$ ), dry haulm weight per plant (17.5 to $74.9 \%), 100$-seed weight (8.1 to $34.3 \%$ ) and pod yield (58.8 to $65.6 \%$ ). However, "ICG-5195" and "SAMNUT 24" formed a sub-cluster within the group. Similarly, "SAMNUT 14" and "SAMNUT 23" were much more genetically identical. Only one cultivar ("ICG-IS-13003") constituted cluster 2. Its mean reduction in height, leaf diameter, number of branches per plant, increased days to 50 $\%$ flowering, reduction in number of pods, pod weight, fresh haulm weight, dry haulm weight, 100 -seed weight and pod yield was $29.6 \%, 29.7 \%$, $30.8 \%$, 1 day, $29.2 \%, 74.6 \%, 63.7 \%, 61.4 \%$, $16.4 \%$, and $74.5 \%$, respectively. Similarly, only one cultivar ("FDRF7-67") formed cluster 3 with $22.8 \%$ height reduction, $14.2 \%$ reduction in leaf diameter, $33.3 \%$ reduction in number of branches and $50 \%$ flowering was delayed for 2 days. Moreover, the cultivar had reduction in number of pods per plant, pod weight per plant, fresh haulm weight per plant, dry haulm weight per plant, 100seed weight and pod yield of 48.1, 62.8, 46.4, 36.4, 50.9 , and $62.4 \%$, respectively.

\section{DISCUSSION}

All cultivars expressed significant variability in morphological and yield traits between the healthy and CABMV-infected plants. This observation showed that CABMV reduced the potential performance of the entire groundnut cultivars evaluated. This supported the findings of Kaitisha (2001) who identified CABMV as a major biotic constraint to groundnut productivity in sub Saharan Africa. Over the years, researchers have intensified efforts aiming at providing adequate protection for plants and obtaining maximum yield. The fact that $100 \%$ disease incidence was found on the inoculated plants indicated that none of the groundnut cultivars exhibited immunity to the virus. Cultivation of tolerant varieties is an alternative and effective control strategy in the absence of immune varieties. The cultivars "ICG-
5195" and "ICG-6654" which exhibited less than $10 \%$ reduction in 100 -seed weight probably contained CABMV tolerant genes.

Seed weight is an important trait because of its direct relationship with seed size (Biçer, 2009), overall yield and economic return. For instance, Upadhyaya et al. (2006) reported seed size as an important trait for trade and component of yield and adaptation in chickpea (Cicer arietinum). In developing countries, including Nigeria most farmers rely on the seeds from previous harvest for field establishment at the next cropping season. Farmers generally prefer varieties with large seeds because such seeds would contain more food for early germination and seedling emergence, vigorous plants and are more likely to produce higher yields. However, since none of the cultivars attained its potential seed weight under infected condition, the top three cultivars "SAMNUT 23", "SAMNUT 25" and "SAMNUT 26" which gave high 100-seed weight among the infected plants could be described as the most tolerant to CABMV disease. Dry matter was least affected in "ICG01276" (less than $20 \%$ reduction) among the infected plants, which revealed some level of tolerance to infection. However, in absolute term, "ICG-92267" which exhibited the highest dry matter among the infected plants could be a choice cultivar for the production of hay in CABMV prone areas. The result of principal components which showed that 100-seed weight was responsible for the greatest variability observed in the growth and yield parameters of both healthy and infected plants. This revealed the importance of seed weight in groundnut breeding.

Cultivars' potential for this parameter was not realized in the CABMV infected plants, thereby revealing the deleterious impact of the virus in susceptible cultivars. The result of cluster analysis was an indication of the variability among the evaluated groundnut cultivars. Cluster 1 consisted of cultivars which could be explored for various purposes. For instance, the cultivars in cluster 1 could be utilized for fresh forage production; "ICG-IS-13003" which is the only member of cluster 2 would be suitable for hay (dry haulm), whereas the cultivar FDRF7-67 that formed cluster 3 would be best for seed production. The inconsistent responses of the cultivars under CABMV disease was partly due to the fact that growth and yield characters were under the influence of different genes. Therefore, it was possibly because the genes conferring disease resistance did not interact synergistically with those controlling growth and yield attributes. This supported the view of Vanhaeren et al. (2016) who reported that growth processes are governed by complex genetic networks. Similarly, studies have shown that in diseased plant, plant-virus interactions interfere with a broad range of cellular 
processes, such as hormonal regulation, cell cycle control and endogenous transport of macromolecules, among others (Pallas and Garcia, 2011). Therefore, the physiology of infected plants was destabilized, resulting in lack of co-ordination among the various organs.

\section{CONCLUSION AND RECOMMENDATIONS}

This study has revealed the vulnerability of some commercial groundnut cultivars and variability in their response to CABMV disease. The infected groundnut cultivars expressed significant reduction for most of the growth and yield traits due to their susceptibility to the pathogen. Although none of the groundnut cultivars exhibited immunity to CABMV disease, some cultivars showed certain levels of tolerance and consequently gave appreciable yield. "SAMNUT 23", "SAMNUT 25" and "SAMNUT 26" were the top three cultivars for 100-seed weight while "ICG-92267" was identified as the best for dry matter production. Planting of these tolerant cultivars is recommended in order to mitigate the stresses imposed by CABMV disease.

\section{REFERENCES}

Adama C.J. Salaudeen M.T., Ishaq M.N., Bello L.Y. and Oyewale, R.O. (2015). Evaluation of Blackeye cowpea mosaic virus pathogenicity in soybean. Nig. J. Agric. Food Environ., 11 (4), 39-44

Adamu A.S., Salaudeen M.T., Gana A.S. and Ishaq M. N. (2015). Response of selected soybean (Glycine max [L.] Merr.) lines to Cucumber mosaic virus disease in Minna, Niger State. Nig. J. Agric. Food Environ., 11 (4), 45-51

Adeboye M.K., Bala A., Osunde A.O., Uzoma, A.O., Odofin A.J. and Lawal B.A. (2011). Assessment of soil quality using soil organic carbon and total nitrogen and microbial properties in tropical agroecosystem. Agric. Sci., 2 (1), 34-40

Alegbejo M.D. (2015). Virus and virus-like diseases of crops in Nigeria, Zaria, Nigeria, Ahmadu Bello University Press, 12, 89-91

Arogundade O., Balogun O.S., Shokalu O. and Aliyu T.H. (2010). Influence of Cowpea mottle virus and Cucumber mosaic virus on the growth and yield of six lines of soybean (Glycine max L. Merrril). J. Agric. Sci., 2 72-78

Badii K.B., Bae A. and Sowley E.N.K. (2013). Efficacy of some lambda-cyhalothrin-based insecticides in control of major field pests of cowpea (Vigna unguiculata L.). Int. J. Sci. Tech. Res., 2 (4), 76-81

Biçer B.T. (2009). The effect of seed size on yield and yield components of chickpea and lentil. Afr. J. Biotech., 8 (8), 1482-1487

Damiri B.V., Al-Shahwan I.M., Al-Saleh M.A., Abdalla O.A. and Amer M.A. (2013). Identification and characterization of Cowpea aphid-borne mosaic virus isolates in Saudi Arabia. J. Plant Path., 95 (1), 79-85

Food and Agriculture Organization (FAO). (2014). Available online at: http://faostat.fao.org/DesktopDefault.aspx?PageID $=339$. Retrieved in July, 2016
Haussmann B.I.G., Fred-Rattunde, H., WeltzienRattunde, E., Traoré, P.S.C., vom Brocke, K., and Parzies H.K., (2012). Breeding strategies for adaptation of pearl millet and sorghum to climate variability and change in West Africa. J. Agron. Crop Sci., 198 (5), 327-33

Janila P., Pandey M.K., Yaduru S., Variath M.sT., Manda S, and Khera P. (2016). Molecular breeding for introgression of fatty acid desaturase mutant alleles (ahFAD2A and $a h F A D 2 B)$ enhances oil quality in high and low oil containing peanut genotypes. Plant Sci., $242203-213$

Janila P., Nigam S.N., Pandey M.K., Nagesh, P. and Varshney R.K. (2013). Groundnut improvement: use of genetic and genomic tools. Frontier Plant Sci., 4, 1-16

Kaitisha G.C. (2001). Some virus diseases of crop plants in Zambia. In: Hughes J, Odu, B.O., (Editors). Plant virology in sub-Saharan Africa. Proc of conference organized by the International Institute of Tropical Agriculture (IITA); June 4-8, 2001. Ibadan, Nigeria

Konlan S., Sarkodie-Addo J., Kombiok M.J., Asare E. and Bawah I. (2013). Yield response of three groundnut (Arachis hypogaea L.) varieties intercropped with maize (Zea mays) in the guinea savanna zone of Ghana. J. Cereals Oilseeds, 6 (32), 76-84

Luis R.G., Arnaldo E.F., Diego D.G, Ana P.O.A.M, Jorge A.M.R. and Elliot W.K. (2013). Alternative hosts of cowpea aphid-borne mosaic virus (CABMV) in sesame (Sesamum indicum) crops grown in Paraguay. Trop. Plant Pathol., 38 (6), 539-542

Muhammad F.S., Muhammad H.S., Muhammad S., Niaz A.Q., and Safia M. (2013). The role of oilseeds nutrition in human health: A critical review. $J$. Cereals Oilseeds, 4 (8), 97-100

Pallas V. and Garcia J.A. (2011). How do plant viruses induce disease? Interactions and interference with host components. J. Gen. Virol., 92 2691-2705

Prasad P.V., Kakani V.G. and Upadhyaya H.D. (2011). Growth and production of groundnut, in soils, plant growth and crop production. [Ed. Willy H., Verheye], in Encyclopedia of Life Support Systems (EOLSS). Developed under the Auspices of the UNESCO, Oxford, UK, Eolss Publishers

SAS (Statistical Analysis System) (2008). Statistical Analysis System SAS/STAT User's guide, ver. 9.2. SAS Institute Inc., Cary, NC

Sastry K.S. and Zitter A. (2014). Plant virus and viroid diseases in the tropics. 2: Epidemiology and Management. New York: Springer

Scott R.K. and Vikas B. (2014). Arachis duranensis. (n.d.). In International Legume Database \& Information Service. Available online at: http://www.ildis.org/Legume

Shoyinka S.A., Thottappilly G., Adebayo G.G. and Anno-Nyako F.O. (1997). Survey on Cowpea virus incidence and distribution in Nigeria. Int. J. Pest Manage., 43 (2), 127-132

NICEF (2007). Available at: http://www.unicef.org/infobycountry/niger_39 675.html (accessed on October 24, 2012).

Upadhyaya H., Kumar S., Gowda C. and Singh S. (2006). Two major genes for seed size in chickpea (Cicer arietinum L.). Euphytica, 147 (3), 311- 315 Vanhaeren, H., Inzé, D. and Gonzalez, N. (2016). Plant growth beyond imits. Trends Plant Sci., 21 (2), 102-109 